\title{
Association of Udder Lesions with Subclinical Mastitis in Dairy Cows of Chattogram, Bangladesh
}

\section{Md. Sanjid Hasan ${ }^{1}$, A K M Humayun Kober ${ }^{1}$, Eaftekhar Ahmed Rana ${ }^{2}$, Md Saiful Bari ${ }^{13,4^{*}}$}

${ }^{1}$ Department of Dairy and Poultry Science, Chattogram Veterinary and Animal Sciences University, Khulshi, Chattogram 4225, Bangladesh; ${ }^{2}$ Department of Microbiology and Veterinary Public Health, Chattogram Veterinary and Animal Sciences University, Khulshi, Chattogram 4225, Bangladesh; ${ }^{3}$ School of Environmental and Rural Science, University of New England, Armidale, New South Wales 2351, Australia; ${ }^{4}$ Agriculture and Food, Commonwealth Scientific and Industrial Research Organisation (CSIRO), Armidale, New South Wales 2350, Australia.

\begin{abstract}
Mastitis is an economically important production disease in Bangladesh. A cross-sectional study was conducted to determine the association of udder lesions with Subclinical Mastitis (SCM) in dairy cows of Chattogram Metropolitan Area (CMA) and Patiya Upazila of Chattogram district during the period from December 2017 to May 2018. For this, 264 milk samples and 155 swab samples were collected from 50 different dairy farms available in CMA and Patiya Upazila. A pretested questionnaire was implemented during sample collection for identifying the associated risk factors of udder lesions and SCM, and to identify the association of udder lesions with SCM. Clinical inspection, palpation and observation were the main tools for determining the udder lesions whereas California Mastitis Tests (CMT) were used for the diagnosis of SCM. Milk samples from CMT positive cows and swab samples from cows' udder surface with lesions were collected for laboratory analysis. Laboratory analysis including bacterial culture and biochemical tests were done to identify the causal agents of SCM and udder lesions. The overall prevalence of SCM and udder lesions were $56.8 \%$ and $32.1 \%$, respectively. Most of the farms under study were small scale (94\%) except a few were medium-scale (6\%). Very few farms used quarantine and isolation shed (6\%) for the disease affected cows. Among the risk factors identified; type of farm, floor type, quarantine facility, isolation shed used, adequate drainage facility were statistically significant $(P \leq 0.05)$ to causing both SCM and udder lesions. Predominant causal agents isolated were Staphylococcus sp 186 (70.4\%), Streptococcus sp 146 (55.3\%), Bacillus sp 62 (23.5\%) and E. coli 20 (7.6\%) from collected CMT positive milk samples. Bacterial cultures of swab samples of udder lesions revealed Staphylococcus sp 120 (77.4\%), Streptococcus sp 112 (72.2\%), E. coli 110 (71.0\%), and Bacillus sp 47 (30.3\%). Moreover, udder lesions were associated with the occurrence of SCM in dairy cows. Therefore, udder damages should be managed carefully to minimise SCM prevalence in dairy cows.
\end{abstract}

\section{Keywords | Bovine mastitis, Causal agents, CMT, Prevalence, Risk factors}

Received | July 29, 2021; Accepted | September 04, 2021; Published | January 04, 2022

${ }^{*}$ Correspondence | Md Saiful Bari, Department of Dairy and Poultry Science, Chattogram Veterinary and Animal Sciences University, Khulshi, Chattogram 4225, Bangladesh; Email: saifulbari@cvasu.ac.bd

Citation | Hasan MS, Kober AKMH, Rana EA, Bari MS (2022). Association of udder lesions with subclinical mastitis in dairy cows of Chattogram, Bangladesh. Adv. Anim. Vet. Sci. 10(2): 226-235.

DOI | http://dx.doi.org/10.17582/journal.aavs/2022/10.2.226.235

ISSN (Online) | 2307-8316

\section{INTRODUCTION}

$\mathrm{M}$ astitis is recognized as one of the most important diseases of dairy cows causing huge economic and production losses to the dairy industry worldwide includ- ing Bangladesh. It is an inflammatory condition of the mammary gland characterized by an increased number of somatic cells in the milk and pathological changes in the mammary tissues (Gianneechini et al.,, 2002), which results in physical, chemical and microbiological changes 
in milk (Seegers et al., 2003). Clinical mastitis is readily visible and easily detected by abnormalities in milk, pathological changes in the udder along with clinical signs (Bari et al., 2014). But in subclinical mastitis, there are no visible changes in milk, udder or general condition except high somatic cell count (SCC) (Sumon et al., 2020).

Subclinical mastitis (SCM) is highly prevalent in both commercial and household dairy farms in Bangladesh. The prevalence of SCM is recorded from $20 \%$ to $44 \%$ based on California Mastitis Test (CMT) at cow level (Rahman et al., 2009; Islam et al., 2010; Rabbani and Samad, 2010). Subclinical mastitis causes heavy economic losses due to reduced milk production, deteriorating milk quality and decreasing milk price due to high bacterial or somatic cell count (Harmon 1994; Singh and Baxi 1994). It also causes increase costs of drugs, veterinary services, herd replacement and problems related to antibiotics residues in milk and its products. In Bangladesh, the annual economic losses due to reduced milk production by SCM have been estimated to be Taka 122.6 (US \$2.11) million (Kader et al., 2003). Singh and Baxi (1994) reported that SCM results in three times more losses as compared to clinical mastitis (CM).

Literature suggested that about 137 biological infectious agents have been causing bovine mastitis. Among infectious agents, bacteria are considered to be the major cause of subclinical mastitis in cattle and other species (E1Rashidy et al., 1996). The most common pathogens responsible for subclinical mastitis include Staphylococcus sp., Streptococcus sp. and Coliforms. Staphylococcus aureus and Streptococcus agalactiae act as contagious pathogens while E. coli, Streptococcus uberis, and Streptococcus dysgalactiae act as environmental pathogens (Radostits et al., 2000; Waller et al., 2009).

The invisible changes in subclinical mastitis can be recognized by several diagnostic methods including the California Mastitis test (CMT), Modified White Side test (MWT), Somatic Cell count (SCC), pH, chlorine and catalase tests. These tests were preferred to be screening tests for subclinical mastitis as they can be used easily and yield rapid as well as satisfying results (Leslie et al., 2002). Among these, CMT is more common in Banladesh, more reliable than MWT, and less expensive than SCC.

Bangladesh has a high number of cattle population 239.35 lakh with about 92.83 lakh metric ton milk production (BBS, 2017). Udder health disorder causes devastating economic loss and a major influence on dairy cows welfare and productivity (Halasa et al., 2007; Hogeveen et al., 2011). Milk quantity, quality and production efficiency of cows is directly dependent on the udder health (Szencziova et al.,
2013). The udder is the most important part of the body of the dairy cow and its morphological and physiological characteristics affect the health of cows and play a vital role in sustainable milk production (Gulyas and Ivancsics, 2002; Tilki et al., 2005; Tancin et al., 2007). It is also recognized that the udder characteristics are very important in respect to milk production as well as for causing mammary infection (Shukla et al., 1997). The physical appearance of the udder and teats are important traits associated with the incidences of subclinical mastitis (Sabin George et al., 2007). The udder is very susceptible to infection and injuries, which results in subclinical mastitis. The morphology of the teat, especially the apex and streak canal are recognized as parts of the passive defence mechanisms against subclinical mastitis infection (Shukla et al., 1997).

Injuries in the udder and teat have been hastening the entry of infectious microorganisms into the udder and cause subclinical mastitis (Islam et al., 2010). Cows with asymmetric udders are more susceptible to injuries and contamination by SCM causing pathogens, which increase the risk of SCM. Therefore, the udder conformation traits can be used to take measures for improving udder health ( $\mathrm{Na}^{-}$ kov et al., 2014). Few studies have revealed that udder and teat lesions act as risk factors for Intra-mammary infection (IMI) (Bhutto et al., 2010). Udder hygiene is also significantly associated with the risk of IMI in cows (Compton et al., 2007). Udder lesions are usually caused by subclinical mastitis pathogens especially Staphylococcus aureus and Streptococcus sp., which increases the chance of injury of the udder. Consequently, the exposure of pathogens to udders increases from the cows' environment. Many risk factors predispose to the high prevalence of SCM in dairy cows of both commercial and household dairy farms. These include host, microbial agents and environmental risk factors. Udder lesions are one of the most important host risk factors that could aggravate the prevalence of the SCM in dairy cows (Francis, 1984).

Moreover, it is important to investigate the relationship of udder and teat lesions with the occurrence of subclinical mastitis with causative agents. Studies on mastitis focusing morphological relationship of udder and teats with mastitis (Ahmed et al., 2005) have been carried out in Bangladesh. However, to the best of our knowledge very few studies have been performed to find out the association of udder lesions with the occurrence of subclinical mastitis in dairy cows of Chattogram, Bangladesh.

Therefore, the study was conducted to reveal the association of udder and teat lesions with the occurrence of SCM in dairy cows. We also estimated the prevalence of udder lesions and SCM with their causal agents and associated risk factors in dairy cows of Chattogram, Bangladesh. 


\section{MATERIALS AND METHODS}

\section{STUDY AREA AND STUDY POPULATION}

Chattogram district has a total area of 168.1 square kilometres, located in between $21^{\circ} 54^{\prime}$ and $22^{\circ} 59^{\prime}$ north latitudes and in between $91^{\circ} 17^{\prime}$ and $92^{\circ} 13^{\prime}$ east longitudes on the banks of the Karnaphuli River. Chattogram Metropolitan Area (CMA) and Patiya upazila were selected for the study. Randomly selected 50 Commercial and household dairy farms of CMA and Patiya Upazila were selected for collecting milk and swab samples. Stratified random sampling methods were applied categorizing the farms into Type A containg $\geq 50$ cows, Type B containing 26-49 cows, and Type C 3- 25 cows. The farm categories are given by the Directorate of Livestock Services (DLS), Bangladesh.

\section{STUdy Design}

A cross-sectional study was conducted to determine the association of udder lesions with subclinical mastitis in dairy cows of Chattogram, Bangladesh. The study was conducted during the period from December 2017 to May 2018. Randomly selected lactating cows in 50 commercial and household dairy farms of CMA and Patiya Upazila were the target population.

\section{DATA COLleCtion}

A validated structured questionnaire was developed and all information relating to the objectives of the study were recorded. The collected data includes the type of housing, management, breed, age, milking system, mastitis related record, and udder or teat abnormalities (alopecia, dermatitis, traumatic, wound, cleft etc.). Data were collected by face to face interviews of the farm owners or the worker of the farms. Sample and data collection were done simultaneously during the study periods.

\section{INSPECTION OF UDDER}

The udder of the cows of selected farms was examined through visual inspection and palpation to detect possible lesions like skin abrasions, hair loss, fibrosis, consistency of mammary quarters, swelling of supra-mammary lymph nodes, dermatitis, traumatic, udder cleft, open wound etc. Selected herds were carefully observed to find out the udder lesions in the lactating cows. Cows under examination were scored based on the magnitude of udder lesions. The following criteria were used for scoring based on the ventral abdomen observation. A total of 6 categories were selected: - Grade 0 = No trace of udder lesions; Grade 1 = Discoloration or moist appearance; Grade $2=$ Hair loss or skin abrasion; Grade 3 = Closed skin crusts or Papillomatosis; Grade 4 = Open wound, no skin; and Grade $5=$ Open wound and bloody, serous, or Purulent exudates (Warnick et al., 2002). During observation, the lesions were photo- graphed and kept stored for further clarification of scoring.

\section{DETECTION OF SUBCLINICAL MASTITIS}

Subclinical mastitis (SCM) was detected based on California Mastitis Test (CMT) results through the nature of coagulation and viscosity of the mixture of milk and CMT reagent, which showed the presence and severity of the subclinical mastitis. The techniques used for CMT are described by Pyorala (2003). Equal quantity (Approx. $3 \mathrm{~mL}$ ) of milk and CMT reagent was added into a white plastic paddle with 4 shallow cups marked $\mathrm{A}, \mathrm{B}, \mathrm{C}, \mathrm{D}$ and the paddle was rotated in a circular motion to mix the content thoroughly for about 10 seconds. The result of the test was indicated based on gel formation. The reactions were observed and noted. The results were interpreted as the criteria described in Table 1.

Table 1: Criteria for scoring of CMT test results

\begin{tabular}{|c|c|}
\hline Category & Description \\
\hline $\mathrm{N}=$ Negative & $\begin{array}{l}\text { No infection, No thickening of the } \\
\text { mixture }\end{array}$ \\
\hline $\mathrm{T}=$ Trace & $\begin{array}{l}\text { Possible infection, Slight thickening } \\
\text { of the mixture, Thickening disappear } \\
\text { on continued rotation }\end{array}$ \\
\hline $1=$ Weak positive & $\begin{array}{l}\text { Infected, Distinct thickening of the } \\
\text { mixture, No gel formation }\end{array}$ \\
\hline $2=$ Distinct positive & $\begin{array}{l}\text { Infected, Immediate thickening of } \\
\text { the mixture, Slight gel formation }\end{array}$ \\
\hline $3=$ Strong positive & $\begin{array}{l}\text { Infected, Gel formation, Surface of } \\
\text { the mixture becomes elevated }\end{array}$ \\
\hline
\end{tabular}

\section{Collection AND TRANSPORTATION OF MILK AND} SWAB SAMPLES

Swab samples collected from udder or teat lesions and California Mastitis Test (CMT) positive milk samples were sampled in this study. Five mL of milk samples per quarter (CMT positive) were collected aseptically in the $15 \mathrm{~mL}$ sterile falcon tube with an identification number. Before sample collection, grossly dirty teats and udders were thoroughly cleaned and dried. Then udder or teat abnormalities were examined. If any udder or teat lesions were present, swab samples were collected aseptically in $5 \mathrm{~mL}$ sterile nutrient broth containing test tube with an identification number. The collection vial was held at $45^{\circ}$ angle to prevent accidentally falling of debris in the collection vial. An individual swab was used for each udder or teat lesion even within the same cows where multiple swabs were taken from different lesions in the same cow. Then all collected samples were immediately transported using an insulated ice box and stored at $-20^{\circ} \mathrm{C}$ before further bacteriological analysis.

\section{ISOLATION AND IDENTIFICATION OF BACTERIA}

The techniques used for the isolation and identification 
of bacteria from collected milk and swab samples were based on the morphological, cultural, colony characteristics, Gram's staining, and biochemical properties including hemolytic activity, catalase test and tube coagulase tests as described by Wilson and Miles (1974). Aso, The techniques used for the preparation of different agar media are described by Hayes (2013).

Staphylococcus aureus grows as large grey or white to yellow colored colonies with beta-hemolytic patterns on blood agar. S. aureus produced small to large yellow zones with color change in MSA but other Staphylococci produced small to large red zones in MSA. Staphylococci were identified based on gram staining, hemolytic activity and the following biochemical reactions: Catalase activity, Tube Coagulase Test (Roberson et al., 1992; Quinn et al., 1994).

\section{STATISTICAL ANALYSis}

The surveyed data, laboratory data and the field data were entered properly in the Microsoft office excel worksheet 2013. Then all the data were carefully checked and analyzed through STATA-11 (STATA Corp, USA). Descriptive analysis was performed using percentages (\%) for all farm-related variables. A Chi-square test was done for determining the associated risk factors of udder lesions with subclinical mastitis. The level of significance was set at 0.05 .

\section{RESULTS}

In this study, two categories of farms were selected. Type B category farms comprising of 26-50 cows, were only 6\% of the total farms under study. Type $\mathrm{C}$ category farms (03-25 cows) in majority consisting $94 \%$ of the total farms under study (Table 2). Most of the farms under study had a concrete floor for their cows but almost $50 \%$ of farms used bedding materials. Around $94 \%$ of farms had no quarantine and isolation shed facility for their cows during disease or emergency conditions (Table 2). On the other hand, maximum farms had adequate drainage facility for the cleanliness of the farms and in $94 \%$ farms, milking the affected animal last were done. Around $42 \%$ of farms have no case clinical mastitis cows during the study but $40 \%$ of farms have one clinical mastitis case at present. Atmost all the farms were used different categories of antibiotics, anti-inflammatory, antihistaminic and others drugs. An enormous number of farms were not practising the dry cow therapy and vaccination against mastitis for their cows and $80 \%$ of farms getting veterinary services (Table 2) under study. $94 \%$ of farms had udder lesions from the total numbers of farms and most of the lesions were present either udder or teat of the lactating cows, only $22 \%$ of farms, where the lesions were present on both udder and teat (Table 3). No lesions were found in $66 \%$ of farms, sin- gle and multiple numbers of udder lesions were found in $30 \%$ and $4 \%$ farms, respectively in dairy cows in the study area (Table 3).

Table 2: Summary of basic parameters of dairy farms of Chattogram

\begin{tabular}{|c|c|c|c|}
\hline Variables & Category & Frequency & $\%$ \\
\hline \multirow[t]{2}{*}{ Farm type } & $\mathrm{B}(26-50)$ & 3 & 6 \\
\hline & $C(3-25)$ & 47 & 94 \\
\hline \multirow[t]{2}{*}{ Floor type } & Concrete & 44 & 88 \\
\hline & Bricks & 6 & 12 \\
\hline \multirow[t]{2}{*}{ Bedding } & Used & 25 & 50 \\
\hline & Not used & 25 & 50 \\
\hline \multirow[t]{2}{*}{ Quarantine } & Yes & 3 & 6 \\
\hline & No & 47 & 94 \\
\hline \multirow[t]{2}{*}{ Isolation shed } & Yes & 3 & 6 \\
\hline & No & 47 & 94 \\
\hline \multirow[t]{2}{*}{ Proper drainage } & Yes & 47 & 94 \\
\hline & No & 3 & 6 \\
\hline \multirow[t]{2}{*}{ Veterinary service } & Yes & 43 & 86 \\
\hline & No & 7 & 14 \\
\hline \multirow{3}{*}{$\begin{array}{l}\text { Drugs used to } \\
\text { treat mastitis last } \\
\text { time }\end{array}$} & Antibiotic & 26 & 52 \\
\hline & Anti-inflammatory & 21 & 42 \\
\hline & Antihistaminic & 3 & 6 \\
\hline \multirow[t]{2}{*}{ Vaccination } & Yes & 12 & 24 \\
\hline & No & 38 & 76 \\
\hline \multirow{6}{*}{$\begin{array}{l}\text { Milk production } \\
\text { of SCM affected } \\
\text { cows }\end{array}$} & $3 \mathrm{~kg}$ & 2 & 4 \\
\hline & $4 \mathrm{~kg}$ & 17 & 34 \\
\hline & $5 \mathrm{~kg}$ & 14 & 28 \\
\hline & $6 \mathrm{~kg}$ & 11 & 22 \\
\hline & $7 \mathrm{~kg}$ & 3 & 6 \\
\hline & $8 \mathrm{~kg}$ & 3 & 6 \\
\hline
\end{tabular}

ASSOCIATION OF RISK FACTORS WITH UDDER LESIONS

\section{IN DAIRY COWS}

Lactating cows of Type- $\mathrm{C}$ farms were more prone to have udder lesions than the Type-B farms lactating cows. The variation of having udder lesions between the two types of farms was statistically significant $(P \leq 0.05)$ (Table 4). Cows reared on concrete type floors were more prone to udder lesions than the cows housed on bricks type floors. This variation was also statistically significant. Farms that were not used in bedding materials had more prone to udder lesions. Farms that had no quarantine and isolation shed facility had more susceptible to the udder lesions and the variation was also statistically significant $(\mathrm{P} \leq 0.05)$ (Table 4).

The farms which had adequate drainage facilities and practiced milking the affected cows last were also more affected 
Table 3: Summary of udder lesions related parameters of dairy farms of Chattogram

\begin{tabular}{llll} 
Variables & Category & Frequency & \% \\
Mastitis affected cows milked last & Yes & 47 & 94 \\
\cline { 2 - 3 } Current clinical mastitis case & No & 3 & 6 \\
& 0 cow & 21 & 42 \\
& 1 cow & 20 & 40 \\
Clinical mastitis last 6 months & 2 cow & 9 & 18 \\
& 0 cow & 12 & 24 \\
\hline Dry cow therapy & 1 cow & 29 & 58 \\
Udder or teat lesions & 2 cow & 9 & 18 \\
Location of lesions (positive cases) & Yes & 15 & 30 \\
& No & 35 & 70 \\
\hline & Yes & 47 & 94 \\
\hline & No & 3 & 6 \\
\hline & Bdder or teat & 39 & 78
\end{tabular}

Table 4: Overall association of risk factors with udder lesions

\begin{tabular}{|c|c|c|c|c|}
\hline \multirow[t]{2}{*}{ Variables } & \multirow[t]{2}{*}{ Category } & \multicolumn{2}{|c|}{ Udder lesions, N (\%) } & \multirow[t]{2}{*}{$\mathbf{P}$} \\
\hline & & Yes & No & \\
\hline \multirow[t]{2}{*}{ Farm type } & $\mathrm{B}(26-50)$ & 0 & $3(100.0)$ & \multirow[t]{2}{*}{0.013} \\
\hline & $C(3-25)$ & $33(66.7)$ & $17(33.3)$ & \\
\hline \multirow[t]{2}{*}{ Floor type } & Concrete & $33(75.0)$ & $11(25.0)$ & \multirow[t]{2}{*}{0.001} \\
\hline & Bricks & 0 & $6(100)$ & \\
\hline \multirow[t]{2}{*}{ Bedding } & Used & $16(64.0)$ & $9(36.0)$ & \multirow[t]{2}{*}{0.77} \\
\hline & Not used & $18(72.0)$ & $7(27.0)$ & \\
\hline \multirow[t]{2}{*}{ Quarantine } & Yes & 0 & $3(100.0)$ & \multirow[t]{2}{*}{0.01} \\
\hline & No & $33(70.2)$ & $14(29.8)$ & \\
\hline \multirow[t]{2}{*}{ Isolation shed } & Yes & 0 & $3(100.0)$ & \multirow[t]{2}{*}{0.01} \\
\hline & No & $33(70.2)$ & $14(29.8)$ & \\
\hline \multirow[t]{2}{*}{ Proper drainage } & Yes & $33(70.2)$ & $14(29.8)$ & \multirow[t]{2}{*}{0.01} \\
\hline & No & 0 & $3(100.0)$ & \\
\hline \multirow[t]{2}{*}{ Milk infected cows last } & Yes & $30(63.8)$ & $17(36.2)$ & \multirow[t]{2}{*}{0.20} \\
\hline & No & $3(100.0)$ & 0 & \\
\hline \multirow[t]{3}{*}{ Current clinical mastitis case } & 0 cow & $16(76.2)$ & $5(23.8)$ & \multirow[t]{3}{*}{0.07} \\
\hline & 1 cow & $14(70.0)$ & $6(30.0)$ & \\
\hline & 2 cow & $3(33.3)$ & $6(66.7)$ & \\
\hline \multirow{3}{*}{$\begin{array}{l}\text { Drugs used to treat mastitis last } \\
\text { time }\end{array}$} & Antibiotic & $20(76.9)$ & $6(23.1)$ & \multirow[t]{3}{*}{0.03} \\
\hline & Anti-inflammatory & $13(61.9)$ & $8(38.1)$ & \\
\hline & Antihistaminic & 0 & $3(100.0)$ & \\
\hline \multirow[t]{2}{*}{ Dry cow therapy } & Yes & $9(60.0)$ & $6(40.0)$ & \multirow[t]{2}{*}{0.56} \\
\hline & No & $24(68.6)$ & $11(32.4)$ & \\
\hline \multirow[t]{2}{*}{ Vaccination } & Yes & $9(75.0)$ & $3(25.0)$ & \multirow[t]{2}{*}{0.45} \\
\hline & No & $24(63.2)$ & $14(36.8)$ & \\
\hline \multirow[t]{2}{*}{ Cull due to mastitis } & Yes & $3(50.0)$ & $3(50.0)$ & \multirow[t]{2}{*}{0.38} \\
\hline & No & $14(31.8)$ & $30(68.2)$ & \\
\hline
\end{tabular}


by the udder lesions. Farms under study which had no or one clinical mastitis cow at present had more udder lesions than the farms which had two clinical mastitis cows. Farms that were not practised dry cow therapy and vaccination against mastitis had more udder lesions than the farms which practised dry cow therapy and used vaccination against mastitis. This variation was statistically significant $(\mathrm{P} \leq 0.05)$ (Table 4). The farms which didn't cull the cows due to mastitis is more udder lesions than the farms which culled the mastitis affected cows.

Prevalence and scoring of subclinical mastitis and udder lesions A total of 445 lactating cows were examined; out of which $253(56.8 \%)$ cows were affected with subclinical mastitis (SCM) based on the CMT and 143 cows out of 445 cows affected by udder or teat lesions (32.1\%). The prevalence of subclinical mastitis and udder lesions has been shown in (Table 5).

Table 5: Overall prevalence and scoring of subclinical mastitis (SCM) and udder lesions

\begin{tabular}{|lll|}
\hline Parameters & Udder lesions, N (\%) & SCM, N (\%) \\
\hline No. of dairy cows & $445(100)$ & $445(100)$ \\
\hline No. of affected cows & $143(32.1)$ & $253(56.9)$ \\
\hline $\begin{array}{l}\text { No. of non-affected } \\
\text { cows }\end{array}$ & $302(67.9)$ & $192(43.1)$ \\
Grade 1 & $17(11.8)$ & $105(41.5)$ \\
Grade 2 & $38(26.6)$ & $98(38.7)$ \\
Grade 3 & $38(26.6)$ & $50(19.8)$ \\
Grade 4 & $32(22.4)$ & - \\
Grade 5 & $18(12.6)$ & -
\end{tabular}

Grade 2 and 3 scorings (26.6\%) udder lesions were found in a higher prevalence rate under study. We found Grade 2 and Grade 3 scoring udder lesions was more prominent than the other grades, and Grade 1 scoring (11.8\%) udder lesions is the lowest percentage in the study area. On the other hand Grade 1 CMT scoring is found highest percentage (42.7\%) and Grade 3 CMT scoring found the lowest percentage $18.6 \%$ (Table 5) under the study area. There was a variation of CMT and udder scores in different individual lactating cows in dairy herds.

\section{Causal agents identified From Subclinical} MASTITIS AND UDDER LESIONS

264 CMT positive milk samples from subclinical mastitis (SCM) affected cows, 155 swab samples from different grade udder lesions were collected and cultured for microbiological examination. From all the cultured samples different bacterial species were isolated (Table 6). Out of 264 milk samples, the predominant isolated bacteria were Staphylococcus spp., with an isolation rate of 186 (70.5\%) and other dominant bacteria isolated were Streptococcus $s p$.
146 (55.3\%), E. 20 (7.6\%), Bacillus sp. 62 (23.5\%), respectively. From 155 swab samples, the predominant isolated bacteria were Staphylococcus sp., with an isolation rate of 120 (77.4\%) followed by Streptococcus sp. 112 (72.3\%) E. 110 (71.0\%), and Bacillus sp. 47 (30.3\%). E.coli found the lowest percentage (7.6\%) in milk samples but Bacillus $s p$. identified the lowest percentage (30.3\%) in collected swab samples (Table 6). We did a tube coagulase test for 100 milk and 100 swab samples and found 26\% Staphylococcus aureus positive in collected milk samples and 17\% Staphylococcus aureus positive results in case of collected swab samples.

Table 6: Causal agents identified from subclinical mastitis (SCM) and udder lesions

\begin{tabular}{|lllll} 
Causal agents & \multicolumn{2}{l}{$\begin{array}{l}\text { Milk samples } \\
\text { (SCM) }\end{array}$} & \multicolumn{2}{l}{$\begin{array}{l}\text { Swab samples (Ud- } \\
\text { der lesions)N=155 }\end{array}$} \\
& $+\mathrm{Ve}$, & $+\mathrm{Ve}$, & $-\mathrm{Ve}$, & $-\mathrm{Ve}$, \\
& $\mathrm{N}(\%)$ & $\mathrm{N}(\%)$ & $\mathrm{N}(\%)$ & $\mathrm{N}(\%)$ \\
Staphylococcus sp. & 186 & 78 & 120 & 35 \\
& $(70.5)$ & $(29.5)$ & $(77.4)$ & $(22.6)$ \\
Streptococcus sp. & 146 & 118 & 112 & 34 \\
& $(55.3)$ & $(44.7)$ & $(72.3)$ & $(27.8)$ \\
E. coli & 20 & 244 & 110 & 45 \\
& $(7.6)$ & $(92.4)$ & $(71.0)$ & $(29.1)$ \\
Bacillus sp. & 62 & 202 & 47 & 108 \\
& $(23.5)$ & $(76.5)$ & $(30.3)$ & $(69.7)$ \\
Staphylococcus & 26 & 74 & 17 & 83 \\
aureus & $(26.0)$ & $(74.0)$ & $(17.0)$ & $(83.0)$
\end{tabular}

\section{DISCUSSION}

The present study investigated the association of udder lesions with subclinical mastitis (SCM) in dairy cows of the selected area of Chattogram, Bangladesh. The present study revealed that udder or teat lesions showed a significant association with the occurrence of subclinical mastitis with the prevalence of $(56.9 \%)$ in dairy cows. This result agreed with the finding of Sori et al. (2005). According to the present study, the prevalence of udder lesions (32.1\%) show a higher value in comparison to that of some previous findings by Waller (2014). The prevalence of lesions in the skin of the udder or teat is much higher than that (0.6-1.4\%) reported in Finland by Saloniemi (1980). The variation in the prevalence of udder lesions between the present and previous studies might be due to the differences in their hygienic management of the farm. The hot humid geo-climatic conditions of the study area might be responsible for the high prevalence of udder lesions with SCM in the present study.

The udder and teats are the first lines of defence against intramammary infection in lactating cows. The teat canal act 
as a physical barrier to the penetration of bacteria. Cows with open udder or teat injuries have a higher risk of acquiring subclinical mastitis than those with no injuries on the udder. It could be due to colonization by pathogenic bacteria into the lesions. This finding was also supported by Sori et al. (2005); Biffa et al. (2005). Udder lesions provide a good medium for the growth of pathogenic bacteria. Lesions are easily invaded by mastitis pathogens especially Staphylococcus sp. and Streptococcus sp., also serve as reservoirs of SCM infection. The same findings are stated by (Klaas et al., 2004; Bhutto et al., 2010; Francis, 1984). The results of the current study revealed that predominant isolated bacteria were Staphylococcus sp., with other dominant isolated bacteria were E. coli, Streptococcus sp. and Bacillus $s p$. from collected samples. The high prevalence of Staphylococcus sp. and Streptococcus sp. were agreed with the findings of Sommerhauser et al. (2003).

The present study suggested that the high prevalence of SCM and udder lesions could reflect inadequate mastitis control and prevention. The control of udder lesions and SCM in dairy herds depends on the identification and elimination of risk factors associated with the environment, animal and farm management. The current study revealed that floor type of the farms, isolation shed, quarantine facility and inadequate drainage facility were responsible for the occurrence of udder lesions with SCM in lactating cows. The finding was supported by Zigo et al. (2021). They found that introducing good management and hygiene measures, selecting dairy cows that are less susceptible to udder lesions and mastitis is also a control measure worthy of consideration. In this study, the low incidence of udder lesions was found in bricks floors compared with concrete floors. This finding was agreed by Nilsson (1988). Lesser incidence rates of udder lesions on bricks floors compared with concrete floors were found by Osteras and Lund (1998).

The present study revealed that udder and teat lesions were acting as a source of bacterial contamination which increases the occurrence of subclinical mastitis, this result found to be agreed with Waller et al. (2014), who stated that the concentration of antibacterial factors in the udder is dependent on udder health and udder lesions aggravate the incidence of subclinical mastitis. This finding was also agreed by Bekele and Molla (2001), who suggested that heavy udder or teat lesions might be responsible for udder infection and lead to subclinical mastitis. The significant association between udder lesions and SCM indicates that udder lesions contributed substantially to the prevalence of SCM in the herds under study.

According to the present study, the prevalence of subclinical mastitis (SCM) was higher and this finding was sim- ilar in comparison to some previous findings. The current result was supported by Rahman et al. (2014); Tripura et al. (2014); Kabir et al. (2017), who reported 50\%-60\% incidences of SCM in dairy cows on bacteriological examination. The finding of the present study was also supported by Kader et al. (2002), who reported a $46.6 \%$ prevalence of SCM in Bangladesh but the results disagreed with the findings of Rahman et al. (2010). This variation in the prevalence of SCM might be due to differences of breed, management systems of the farms, the difference in the handling of lactating cows and tests used for screening of milk samples (Mekonnen et al.,, 2017). The present study also revealed a close positive relationship between the isolation of bacteria from milk samples and the California mastitis test (CMT). Specific bacteria were isolated from all CMT positive milk samples. That means that CMT was a good diagnostic tool in the detection of SCM. Hence it could be the most reliable test to investigate SCM in dairy farms. The findings were agreed with the results of Motie et al. (1985), Bekele and Molla, (2001) they reported a strong positive correlation between the CMT scores and isolated bacteria from bacteriological results.

In this current study, Staphylococcus sp., E. coli, Bacillus sp. and Streptococcus $s p$. were isolated from the California mastitis test positive milk samples. The predominant isolated bacteria in the present study were Staphylococcus and Streptococcus. The present study revealed that Staphylococcus sp. was the major pathogen with a significantly higher incidence rate, followed by Streptococcus sp., Bacillus sp. and E. coli were also found from subclinical mastitis affected cows in different incidence rates. The result was supported by the findings of Sumon et al. (2017); Shike et al. (1998), who reported the highest incidence rate of Staphylococci, followed in order by Streptococci, E. coli, and Bacillus sp. and Staphylococci was the chief pathogens causing subclinical mastitis. But this result is dissimilar with the findings of Harjanti et al. (2018) who stated that Streptococcus sp. was the predominant isolated species (73.3\%). It might be due to regional variation of the study area. The increased incidence of pathogenic bacteria recorded in this current study, in comparison to the earlier findings of Mahbub-E-Elahi et al. (1996), might be due to improper herd health management with indiscriminate use of antibiotics that lead to antibiotic resistance in dairy cows.

\section{CONCLUSIONS AND RECOMMENDATIONS}

Overall, significant numbers of lactating cows had SCM and udder lesions which are major health problems of dairy cows and might cause significant loss to dairy farmers. The chances of SCM were higher in cows having lesions of hair loss or skin abrasion, skin crusts or papillomatosis in 
their udder/ teats. The occurrence of SCM and udder lesions is closely associated with the poor condition of the cows, floor type of the farms, isolation shed of the farms and injuries to the skin of the udder or teat. The study determined a high prevalence of bovine SCM (56.9\%) with a medium prevalence of udder lesions (32.1\%). Both contagious and environmental pathogens including Staphylococcus sp., Streptococcus sp., E. coli, Bacillus sp. and S. aureus were isolated. Of these, Staphylococcus sp. and Streptococcus $s p$. were the predominant isolates. Both mild and severe udder lesions were found at higher percentage in dairy herds, which emphasizes the need for implementing different preventive measures and efficient treatments. The udder lesions have a greater chance to cause SCM which can be used as an important parameter in the monitoring of SCM control. Further study is suggested to confirm the present results and observations. The causative mechanism of udder lesions and its potential preventive factors still need to be elucidated. The association between udder lesions and subclinical mastitis varies with the genetic compositions of the dairy cows. Therefore, further sudy including PCR based diagnosis of pathogens is required confirm the association of udder lesions with SCM in dairy cows.

The study on the determination of association of udder lesions with SCM in dairy cows of Chattogram, Bangladesh suggests continuous and regular screening of cows for SCM at farms, identified risk factors should be minimized, reducing the risk of contamination through improving the farm hygiene, and influences record keeping of the cows and farms.

\section{ACKNOWLEDGEMENTS}

We, the authors, are grateful to the Chattogram Veterinary and Animal Sciences University (CVASU) for funding the research. We would acknowledge the farmers of Chattogram for their cooperation. Also, the authors would give thanks to Poultry Research and Training Centre (PRTC) for providing laboratory facilities.

\section{AUTHORS' CONTRIBUTION}

MSB conceived and designed the study. MSH and EAR did the fieldwork and data collection. MSB and MSH did the analysis. MSH drafted the manuscript with the help of MSB. AKMHK reviewed the manuscript critically. All the authors reviewed and agreed with the final contents of the manuscript.

\section{CONFLICT OF INTERESTS}

The authors declared they have no conflict of interests.

\section{REFERENCES}

Ahmed JU, Sutradhar S, Rahman MM (2005). Morphological characteristics of udders and teats in relation to mastitis and milk yield in crossbred dairy cows. Bangladesh Vet. 22: 2328.

Bari MS, Alam M, Uddin M, Rahman MK (2014). Prevalence and associated risk factors of bovine clinical mastitis in Patiya upazila under Chittagong district of Bangladesh. Intl. J. Nat. Sci. 4 (1): 5-9. https://doi.org/10.3329/ijns.v4i1.28585

BBS (2017). Yearbook of Agricultural Statistics of Bangladesh. Bangladesh Bureau of Statistics. Government of the People's Republic of Bangladesh. pp. 253.

Bekele T, Molla B (2001). Mastitis in lactating camels (Camelus dromedarius) in Afar Region, north-eastern Ethiopia. Berliner und Munchener Tierarztliche Wochenschrift. 114 (5-6): 169-172.

Bhutto AL, Murray RD, Woldehiwet Z (2010). Udder shape and teat-end lesions as potential risk factors for high somatic cell counts and intra-mammary infections in dairy cows. Vet. J. 183(1): 63-67. https://doi.org/10.1016/j.tvj1.2008.08.024

Biffa D, Debela E, Beyene F (2005). Prevalence and risk factors of mastitis in lactating dairy cows in Southern Ethiopia. Intl. J. Appl. Res. Vet. Med. 3(3): 189-198.

Compton CWR, Heuer C, Parker K, McDougall S (2007). Epidemiology of mastitis in pasture-grazed peripartum dairy heifers and its effects on productivity. J. Dairy Sci. 90(9): 4157-4170. https://doi.org/10.3168/jds.2006-880

EI-Rashidy AA, Sobhy MM, Kadry RM, Kholeaf ZM (1996). Studies on Different Causative Agents of Bovine Mastitis. Zag. Vet. J. 24(4): 51-59.

Francis PG (1984). Teat skin lesions and mastitis. British Vet. J. 140 (5): 430-436. https://doi.org/10.1016/00071935(84)90036-8

Gianneechini R, Concha C, Rivero R, Delucci I, López JM (2002). Occurrence of clinical and sub-clinical mastitis in dairy herds in the West Littoral Region in Uruguay. Acta Vet. Scand. 43 (4): 221. https://doi.org/10.1186/17510147-43-221

Gulyas L, Ivancsics J (2002). Relationship between the somatic cell count and certain udder-morphologic traits. Acta Vet. Hung. 50: 373-383.

Halasa T, Huijps K, Østerås O, Hogeveen H (2007). Economic effects of bovine mastitis and mastitis management: A review. Vet. Quart. 29(1): 18-31. https://doi.org/10.1080/01 652176.2007.9695224

Harjanti DW, Ciptaningtyas R, Wahyono F, Setiatin ET (2018). Isolation and identification of bacterial pathogen from mastitis milk in Central Java Indonesia. In IOP Conference Series: Earth and Environmental Science (Vol. 102, No. 1, p. 012076): IOP Publishing. 38 https://doi.org/10.1088/17551315/102/1/012076

Harmon RJ (1994). Physiology of mastitis and factors affecting somatic cell counts1.J. Dairy Sci. 77(7): 2103-2112.https:// doi.org/10.3168/jds.S0022-0302(94)77153-8

Hayes R (2013). Food microbiology and hygiene. Springer Science \& Business Media.

Hogeveen H, Huijps K, Lam TJGM (2011). Economic aspects of mastitis: new developments. New Zealand Vet. J. 59(1): 16-23. https://doi.org/10.1080/00480169.2011.547165

Islam MA, Islam MZ, Rahman MS, Islam MT (2010). Prevalence of subclinical mastitis in dairy cows in selected areas of Bangladesh. Bangladesh J. Vet. Med. 9(1): 73-78. 
https://doi.org/10.3329/bjvm.v9i1.11216

Islam MA, Rahman AKMA, Rony SA, Islam MS (2010). Prevalence and risk factors of mastitis in lactating dairy cows at Baghabari milk shed area of Sirajgonj. Bangladesh J. Vet. Med. 8(2): 157 - 162. https://doi.org/10.3329/bjvm. v8i2.11200

Kabir MH, Ershaduzzaman M, Giasuddin M, Nazir KNH, Mahmud MM, Islam MR, Ali MY (2017). Prevalence and molecular detection of the causal agents of sub-clinical mastitis in dairy cows in Sirajganj and Pabna districts, Bangladesh.J.Adv. Vet. Anim. Res. 4 (4): 378 - 384. https:// doi.org/10.5455/javar.2017.d238

Kader MA, Samad MA, Saha S, Taleb MA (2003). Prevalence and etiology of subclinical mastitis with antibiotic sensitivity to isolated organisms among milch cows in Bangladesh. Indian J. Dairy Sci. 55(4): 218-23.

Klaas IC, Enevoldsen C, Vaarst M, Houe H (2004). Systematic clinical examinations for identification of latent udder health types in Danish dairy herds. J. Dairy Sci. 87(5): 1217-1228. https://doi.org/10.3168/jds.S0022-0302(04)73272-5

Leslie KE, Jansen JT, Lim GH (2002). Opportunities and implications for improved on-farm cow side diagnostics. In Proc. De Laval Hygiene Symp (Vol. 147).

Mahbub-E-Elahi ATM, Rahman MM, Prodhan MAM (1996). Isolation and identification of bacteria from different quarters of mastitis affected dairy cows in Bangladesh. Vet. J. 30 (1-2): 63-65.

Mekonnen S A, Koop G, Melkie S T, Getahun CD, Hogeveen H, Lam TJ (2017). Prevalence of subclinical mastitis and associated risk factors at cow and herd level in dairy farms in North-West Ethiopia. Prev. Vet. Med. 145: 23-31. https:// doi.org/10.1016/j.prevetmed.2017.06.009

Motie A, Ramudit S, Mohabir R (1985). Subclinical mastitis in dairy cattle in Guyana. Trop. Anim. Health. Prod. 17 (4): 245-246. https://doi.org/10.1007/BF02356987

Nakov D, Hristov S, Andonov S, Trajchev M (2014). Udderrelated risk factors for clinical mastitis in dairy cows. Vet. Arch. 84 (2): 111-127.

Nilsson C (1988). Floors in animal houses. Dissertation. Report 61, LBT, Swedish University of Agricultural Sciences, Lund, Sweden.

Osteras O, Lund A (1988). Epidemiological analyses of the associations between bovine udder health and housing. Prev. Vet. Med. 6:79-90. https://doi.org/10.1016/01675877(88)90046-3

Pyorala S (2003). Indicators of inflammation in the diagnosis of mastitis. Vet. Res. 34 (5): 565-578. https://doi.org/10.1051/ vetres:2003026

Quinn PJ, Carter ME, Marker BK, Carter GR (1994). Clinical Veterinary Microbiology. 4th Ede, Mosby-Year Book, Europe Limited, Spain.

Rabbani AFMG, Samad MA (2010). Host determinants based comparative prevalence of subclinical mastitis in lactating Holstein-Friesian cross cows and Red Chittagong cows in Bangladesh. Bangladesh J. Vet. Med. 8 (1): 17-21. https:// doi.org/10.3329/bjvm.v8i1.7397

Radostits OM, Blood DC, Gay CC, Hinchcliff KW. 2000. Veterinary Medicine. 9th edi. WB Saunders, China.

Rahman F, Chowdhury S, Rahman MM, Ahmed D, Hossain A (2009). Antimicrobial resistance pattern of gram-negative bacteria causing urinary tract infection. Stamford J. Pharm. Sci. 2(1): 44-50. https://doi.org/10.3329/sjps.v2i1.5815

Rahman MM, Islam MR, Uddin MB, Aktaruzzaman M (2010).
Prevalence of subclinical mastitis in dairy cows reared in Sylhet district of Bangladesh. Intl. J. Bio. Res, 1(2): 23-28.

Rahman MM, Munsi MN, Ekram MF, Kabir MH, Rahman MT, Saha S (2014). Prevalence of subclinical mastitis in cows at Anwara, a coastal Upazila of Chittagong district in Bangladesh. J. Vet. Adv. 4(6): 594-598.

Roberson JR, Fox LK, Hancock DD, Besser TE (1992). Evaluation of methods for differentiation of coagulasepositive staphylococci. J. Clin. Microb. 30 (12): 3217-3219. https://doi.org/10.1128/jcm.30.12.3217-3219.1992

Sabin George, Joshi HC, Suman CL, Rathore RS, Bisht GS (2007). Incidences of subclinical mastitis in crossbred cattle herd. Indian J. Anim. Prod. Mgmt. 23(1-4) :1-4.

Saloniemi H (1980). Udder diseases in dairy cows-field observations on incidence, somatic and environmental factors, and control. J. Sci. Agri. Soc. Finland. 52(2): 85-184 https://doi.org/10.23986/afsci.72033.

Seegers H, Fourichon C, Beaudeau F (2003). Production effects related to mastitis and mastitis economics in dairy cattle herds. Vet. Res. 34 (5): 475-491. https://doi.org/10.1051/ vetres:2003027

Shike DD, Keskar DV, Jagadish S, Bhalero DP, Sharma LK (1998). Subclinical and clinical mastitis in cross bred cows: etiology and antimicrobial sensitivity. Indian Vet. J. 75 (5): 458-459.

Shukla SK, Dixit VP, Thapliyal DC, Garg SK, Kumar A (1997). A note on the incidence of bovine mastitis in relation to teat shape, size and quarters affected. Indian Vet. J. 74 (11).

Singh KB, Baxi KK (1994). Studies on the incidence and diagnosis of subclinical mastitis in milch animals. Indian Vet. J. 57(9): 723-729.

Sommerhäuser J, Kloppert B, Wolter W, Zschöck M, Sobiraj A, Failing K (2003). The epidemiology of Staphylococcus aureus infections from subclinical mastitis in dairy cows during a control programme. Vet. micr. 96(1): 91-102. https://doi.org/10.1016/S0378-1135(03)00204-9

Sori H, Zerihun A, Abdicho S (2005). Dairy cattle mastitis in and around Sebeta, Ethiopia. J. Appl. Res. Vet. Med. 3(4): 332.

Sumon S, Parvin M S, Ehsan MA, Islam MT (2020). Relationship between somatic cell counts and subclinical mastitis in lactating dairy cows. Vet. World 13(8): 1709-1713. https:// doi.org/10.14202/vetworld.2020.1709-1713

Sumon, SMMR, Ehsan MA, Islam MT (2017). Subclinical mastitis in dairy cows: somatic cell counts and associated bacteria in Mymensingh, Bangladesh. J. Bangladesh Agri. Uni. 15 (2): 266-271. https://doi.org/10.3329/jbau. v15i2.35073

Szencziová I, Strapák P, Stádník L, Ducháček J, Beran, J (2013). Relationship of Udder and Teat Morphology to Milking Characteristics and Udder Health Determined by Ultrasonographic Examinations in Dairy Cows/Związek Między Morfologią Wymienia I Strzyków A Cechami Doju I Zdrowotnością Wymienia W Badaniach Usg Krów Mlecznych. Annals of Anim. Sci. 13(4): 783-795. https:// doi.org/10.2478/aoas-2013-0053

Tancin V, Uhrincat M, Mihina S, Sudzinova J, Foltys V, Tancinova D (2007). Somatic cell count and quarter milk flow parameters from udder of dairy cows. Slovak J. Anim. Sci. 40: 79-82.

Tilki M, Inal S, Colak M, Garip M (2005). Relationships between milk yield and udder measurements in Brown Swiss cows. Turkish J. Vet. Anim. Sci. 29 (1): 75-81. 
Tripura TK, Sarker SC, Roy SK, Parvin MS, Sarker RR, Rahman AKMA, Islam MT (2014). Prevalence of subclinical mastitis in lactating cows and efficacy of intramammary infusion therapy. Bangladesh J. Vet. Med. 12 (1): 55-61. https://doi. org/10.3329/bjvm.v12i1.20464

Waller KP, Bengtsson M, Nyman AK (2014). Prevalence and risk factors for udder cleft dermatitis in dairy cattle. J. Dairy Sci. 97(1): 310-318. https://doi.org/10.3168/jds.2013-7186

Waller KP, Bengtsson B, Lindberg A, Nyman A, Ericsson UH (2009). Incidence of mastitis and bacterial findings at clinical mastitis in Swedish primiparous cows influence of breed and stage of lactation. Vet. Microb. 134: 89-94. https://doi. org/10.1016/j.vetmic.2008.09.004

Warnick LD, Nydam D, Maciel A, Guard CL, Wade SE (2002). Udder cleft dermatitis and sarcoptic mange in a dairy herd. J. American Vet. Med. Assoc. 221 (2): 273-276. https://doi. org/10.2460/javma.2002.221.273

Wilson GS, Miles A (1974). Topley and Wilson's Principles of Bacteriology, Virology and Immunology. 5th edn, Edward Arnold Ltd., London

Zigo F, Vasil M, Ondrašovičová S, Výrostková J, Bujok J, PeckaKielb E (2021). Maintaining Optimal Mammary Gland Health and Prevention of Mastitis. Front. Vet. Sci. 8: 69. https://doi.org/10.3389/fvets.2021.607311 